\title{
Belkin L.M.•
}

DOI: 10.25108/2304-1730-1749.iolr.2017.52.21-77

\section{Legal basis for decommunization in Ukraine: The law on the condemnation of the communist and national-socialist (nazi) totalitarian regimes in Ukraine as the central law of Ukrainian de-communization}

\begin{abstract}
On the basis of the Laws of Ukraine "On the Rehabilitation of Victims of Political Repression in Ukraine" (No. 962-XII of 04/17/1991), "On the Holodomor of 1932-1933 in Ukraine" (No. 376-V of 28/11/2006), "On the condemnation of the communist and national-socialist (Nazi) totalitarian regimes in Ukraine and the prohibition of propaganda of their symbols" (No. 317-VIII of 09/04/2015) examines the legal basis for decommunization in Ukraine. It is emphasized that the communist ideology used anywhere or ever, whether in Europe or elsewhere, has always led to mass terror, crimes and human rights violations on a large scale. This fully applies to the USSR in general and to Ukraine in particular. The main provisions of these laws are considered, some of the most common objections to these laws are refuted, the nature of these objections is clarified.
\end{abstract}

Keywords: OSCE, the Council of Europe; de-communization; communist ideology; Nazi ideology; the identification of communism and Nazism; totalitarianism; the communist totalitarian regime; the national-socialist (Nazi) totalitarian regime; the Holodomor; genocide; political repression; historical memory; violation of human rights; deportation of peoples.

Section III of the resolution of the Parliamentary Assembly of the Council of Europe (PACE) of 27/06/1996 No. 1096 (1996) "The need for international

\footnotetext{
- Belkin Leonid Mikhailovich - Candidate of Technical Sciences, Senior Researcher, Director of the consulting firm «Analytic» (Kramatorsk, Donetsk region, Ukraine), e-mail: belkinajulia@ list.ru
} 
condemnation of the crimes of totalitarian communist regimes" indicates that the communist ideology applied anywhere or ever, Europe, or elsewhere, has always led to massive terror, crimes and human rights violations on a large scale ${ }^{1}$. Thus, decommunization is a factor in international politics and international law.

Among all the peoples affected by the practical embodiment of communist ideology, Ukraine has a special account. Thus, in the preamble of the Law "On the Rehabilitation of Victims of Political Repression in Ukraine", it is stated that after 1917, during the civil war and subsequent decades, a lot of human blood was spilled on the land of Ukraine. Millions of innocent people, on the basis of antihuman and anti-democratic laws and as a result of direct lawlessness and arbitrariness, were persecuted for their political activities, statements and religious beliefs. The most serious legacy of the past is the massive repression that was committed by the Stalinist regime and its agents in the republic. Judicial and extrajudicial executions grossly violated the norms of the Constitution, designed to protect the rights and freedoms of citizens, the elementary norms of legal proceedings.

According to research carried out by the Institute of History of Ukraine of the National Academy of Sciences of Ukraine, the demographic loss of Ukraine in the first half of the 20th century estimated at about 15 million people [16]. It's about people who died or were forcibly deported outside their homeland. For the population of Ukraine, by 1914 not exceeding 40 million people within the present borders, the losses of this scale were truly catastrophic. It points to several types of terror that affected the demographic situation in the country: terror by famine (15 million people included 3.5 million people who died from hunger, although according to some other, more recent estimates, these losses reach 8.4 million [10]), the deportation of the population outside the Ukrainian SSR, mass arrests with subsequent imprisonment or immediate execution [16]. Therefore, for

\footnotetext{
${ }^{1}$ http://www.portal-credo.ru/site/?act=news\&id=39933
} 
Ukraine, decommunization is an important act of restoring historical justice [5] and historical memory. As the professor of Quebec University of Canada R. Serbin notes, "the problem of Ukraine is that for more than 20 years the Ukrainian elite has failed to correctly comprehend the Soviet period and could not transfer this to the Ukrainian population, especially children" [26].

There is something to show the Bolshevik regime and Azerbaijan. Thus, Article 1 of the Constitutional Act of the Republic of Azerbaijan No. 222-XII of 18/10/1991 "On Restoration of State Independence of the Republic of Azerbaijan" states that to regard the intervention of the Russia's 11th Red Army to Azerbaijan on April 27-28 of 1920, the occupation of the territory of the Republic, the overthrow of the Democratic Republic of Azerbaijan as the component of the international law the occupation of the independence Azerbaijan by [bolshevik] Russia $^{2}$. During the suppression of the Ganja uprising of 1920 (Gəncə üsyan1), the first armed attack against Sovietization of Azerbaijan, the Bolsheviks killed up to 3.500-4.000 civilians (according to some Western sources - up to 15.000), the entire Muslim part of the city was destroyed, among the dead were children aged 2-3 years [18].

The Polish historian Mariusz Volos, commenting on the Polish decommunization law of 22/06/2017, notes that in relation to the history of our country (Poland - author's comment), it should be mentioned that Poland was an independent state until 1939. And after 1944-45 it depended on Moscow. And, considering this circumstance, the monuments to the Red Army soldiers for us remain, first of all, a symbol of submission [19].

Thus, the theoretical and practical problems of decommunization somehow arise in front of all post-Soviet countries.

In Ukraine, the history of the legal regulation of decommunization can be counted off from the adoption of the above mentioned Law "On the rehabilitation

\footnotetext{
${ }^{2}$ Quotation by source: http://azerbaijan.az/portal/History/HistDocs/Documents/en/09.pdf
} 
of victims of political repression in Ukraine". In the preamble of this law, in particular, it is stated that the Verkhovna Rada of Ukraine condemns repression and dissociates itself from the terrorist methods of governing the society..., declares its intention to steadily seek restoration of justice, elimination of consequences of arbitrariness and violation of civil rights... guarantees to the people of Ukraine that this will never happen again, that human rights and the rule of law will be sacredly respected.

Thus, the overcoming of the consequences of Bolshevism was also associated with the restoration of the rule of law and guarantees for the observance of human rights.

The preamble of the Law of Ukraine "On the Holodomor of 1932-1933 in Ukraine" includes, in particular, condemning the criminal actions of the totalitarian regime of the USSR aimed at organizing the Holodomor, which resulted in the destruction of millions of people, the destruction of the social foundations of the Ukrainian people, its centuries-old traditions, spiritual culture and ethnic identity. High appreciation of solidarity and support from the international community, reflected, inter alia, in the Joint Statement of 07/11/2003 by the delegations of the UN member states on the 70th anniversary of the Holodomor in Ukraine, 1932-33, was signed, including, and Azerbaijan. The statement, in particular, indicates that in the former Soviet Union, millions of men, women and children fell victims to the cruel actions and policies of the totalitarian regime. The Great Famine of 19321933 in Ukraine (Holodomor), which took from 7 million to 10 million innocent lives and became a national tragedy for the Ukrainian people ${ }^{3}$.

The logical continuation of the process of creating the legal basis for decommunization is the adoption on 09/04/2015 of a package of 4 laws, which in public speeches and society as a whole have been called 'de-communization' laws. Such laws include the laws "On the condemnation of the communist and national-

\footnotetext{
${ }^{3}$ Quotation by source: http://repository.un.org/bitstream/handle/11176/246001/A_C.3_58_9EN.pdf? sequence $=3 \&$ isAllowed $=y$
} 
socialist (Nazi) totalitarian regimes in Ukraine and the prohibition of propaganda of their symbols" (Law No.317-VIII); "On perpetuation of the victory over Nazism in World War II of 1939-1945” (Law No. 315-VIII), “On the Legal Status and Honoring the Memory of Fighters for Ukraine's Independence in the Twentieth Century" (Law No. 314-VIII) and "On access to Archives of Repressive Agencies of Totalitarian Communist Regime of 1917-1991" (Law No. 316-VIII). The basic among these laws should be considered as Law No. 317-VIII, since all other laws somehow proceeded from the necessity and legality of condemning the communist and national-socialist (nazi) totalitarian regimes in Ukraine. The legal analysis of the specifics of these laws was partially carried out by the author in [5], and in addition the analysis of Law No. 316-VIII was performed in [25].

The adopted laws caused the expected criticism among Russian and proRussian politicians, as well as supporters of leftist and left-liberal ideas [4, 5]. "Equalizing the communist and Nazi attributes on the eve of the 70th anniversary of the Great Victory is both cynical and sacrilegious at the same time", - said Slutsky, chairman of the State Duma Committee for CIS Affairs. "The prohibition of symbolism is unconstitutional and is an attempt to divert attention from the total failure and bankruptcy of the current authorities", - A. Martyniuk, second secretary of the Central Committee of the Communist Party, responded. The leader of the Party of the Communist Renewal of Italy P. Ferrero called on his government to withdraw from Kiev ambassador, and the representative of the Communist Party of Spain H. de Dios Villanueva told that the world communist movement will seek to attract attention to such discrimination at the international level, including the UN [1]. The MP from the then Opposition bloc N. Korolevskaya called these laws 'dictatorial' and stressed that these laws pave the way for the conviction and persecution of people for their views and convictions, for the dictatorship, the heyday of the new totalitarianism in the country [12]. To the criticism of the laws, representatives of some organizations 
that consider themselves 'guardians' of democracy unexpectedly joined in. For example, OSCE Representative on Freedom of the Media, D. Miyatovich, expressed concern that the decommunization law threatens freedom of speech and the media [26]. The European Commission for Democracy through Law (Venice Commission), on the whole, not objecting to Ukraine's right to pass laws on decommunization, spoke in the sense that the law: a) the concept of 'propaganda' is too broadly defined; b) there is a difference between the approaches to Nazism and communism in Law No. 317-VIII; c) there are disproportionate sanctions for violators $[4,21]$. It is very appropriate to note that the Venice Commission and the OSCE actually torpedoed decommunization in Moldova. Thus, in the Decree of 04/06/2013 No. 12, the Constitutional Court of the Republic of Moldova, referring to the findings of these institutions, recognized as unconstitutional the provisions of the Moldovan legislation prohibiting political parties to use the symbols of a totalitarian communist regime and propaganda of totalitarian ideologies, and also providing responsibility for such actions ${ }^{4}$ (par 128). Thus, already the laws on 'decommunization' become a factor in international politics and international law.

It should be noted that, at the level of general political and general legal conclusions, European democratic institutions 'did not hesitate' to identify communism and National Socialism (Nazism). So, in the preamble to the Law No. 317-VIII it is stated ${ }^{5}$ that the law was adopted, being guided by the Universal Declaration of Human Rights, considering the resolutions of the Council of Europe Parliamentary Assembly No. 1096 (1996) dated 27 June 1996 on measures to dismantle the heritage of former communist totalitarian systems, No. 1481 (2006) dated 26 January 2006 Need for international condemnation of crimes of totalitarian communist regimes, No. 1495 (2006) dated 12 April 2006 Combating

\footnotetext{
${ }^{4}$ Quotation by source: http://lex.justice.md/ru/349032/

5 Hereinafter referred to as Law No.317-VIII is cited in the English text on the resource http://www.memory.gov.ua/laws/law-ukraine-condemnation-communist-and-national-socialist-naziregimes-and-prohibition-propagan
} 
the resurgence of Nazi ideology, No. 1652 (2009) dated 29 January 2009 Attitude to memorials exposed to different historical interpretations in Council of Europe member states, Resolution of the OSCE Parliamentary Assembly SC (09) 3 R dated 29 June - 3 July 2009 not to glorify totalitarian regimes, to open historical and political archives, to continue research into and raise public awareness of the totalitarian legacy, Declaration of the European Parliament of 23 August 2008 on the proclamation of 23 August as European Day of Remembrance for Victims of Stalinism and Nazism, European Parliament resolution of 23 October 2008 on the commemoration of the Holodomor, the Ukraine artificial famine (1932-1933), European Parliament resolution of 02 April 2009 on European conscience and totalitarianism, the Joint Statement issued at the 58th Plenary Session of the UN General Assembly on the 70th Anniversary of the Holodomor in Ukraine.

Thus, PACE Resolution No. 1481 (2006) of 26/01/2006 states that the fall of totalitarian communist regimes in central and eastern Europe has not been followed in all cases by an international investigation of the crimes committed by them. Moreover, the authors of these crimes have not been brought to trial by the international community, as was the case with the horrible crimes committed by National Socialism (Nazism).Consequently, public awareness of crimes committed by totalitarian communist regimes is very poor. Communist parties are legal and active in some countries, even if in some cases they have not distanced themselves from the crimes committed by totalitarian communist regimes in the past.The Assembly is convinced that the awareness of history is one of the preconditions for avoiding similar crimes in the future. Furthermore, moral assessment and condemnation of crimes committed play an important role in the education of young generations. The clear position of the international community on the past may be a reference for their future actions. Totalitarian communist regimes are still active in some countries of the world and crimes continue to be committed. National interest perceptions should not prevent countries from adequate criticism 
of current totalitarian communist regimes. The Assembly calls on all communist or post-communist parties in its member states which have not yet done so to reassess the history of communism and their own past, clearly distance themselves from the crimes committed by totalitarian communist regimes and condemn them without any ambiguity ${ }^{6}$.

PACE Resolution No. 1652 (2009) of 29/01/2009 emphasizes that in order to enable individual Council of Europe member states to come to terms with the controversies of their recent past, Europe must unequivocally reject and unreservedly condemn all forms of dictatorial regimes such as National Socialism, fascism and totalitarian communism. In this context the Assembly deems it necessary to distinguish between war graves and victory monuments erected to glorify totalitarian regimes or former occupation forces - or at least perceived as such by the majority population. It underlines that, where graves and burial sites containing the remains of foreign soldiers and war victims are concerned, national decisions must fully abide by the respect for the dead, often victims rather than occupiers, and bilateral or multilateral agreements, notably Protocol I to the Geneva Conventions relating to the Protection of Victims of International Armed Conflicts ${ }^{7}$.

In the resolution of the OSCE Parliamentary Assembly from 29/0603/07/2009 (Resolution on divided Europe reunited: promoting human rights and civil liberties in the OSCE region in the 21st century) states that in the twentieth century European countries experienced two major totalitarian regimes, Nazi and Stalinist, which brought about genocide, violations of human rights and freedoms, war crimes and crimes against humanity; is expressed deep concern at the glorification of the totalitarian regimes, including the holding of public demonstrations glorifying the Nazi or Stalinist past, as well as the possible spread and strengthening of various extremist movements and groups, including neo-

\footnotetext{
${ }^{6} \mathrm{http} / / /$ assembly.coe.int/nw/xml/XRef/Xref-XML2HTML-en.asp?fileid=17403\&lang=en

${ }^{7}$ http://assembly.coe.int/nw/xml/XRef/Xref-XML2HTML-en.asp?fileid=17713\&lang=en
} 
Nazis and skinheads ${ }^{8}$.

In the declaration of 23/09/2008, the European Parliament, pointing out that the mass deportations, murders and enslavements committed in the context of the acts of aggression by Stalinism and Nazism fall into the category of war crimes and crimes against humanity, declared August 23, i.e. the day of the signing of the Molotov-Ribbentrop Pact, the European Day of Remembrance for the Victims of Stalinism and Nazism in the name of preserving the memory of the victims of mass deportations and executions. Initially, this was stated and supported in the resolution of the OSCE Parliamentary Assembly from 29/06-03/07/2009. Continuing this theme, on 02/04/2009, in memory of the consequences of the pact, the European Parliament adopted the resolution «European Consciousness and Totalitarianism». The resolution calls on the member states of the European Parliament to declare August 23 a European Day of Remembrance for the victims of all totalitarian and authoritarian regimes, a memory that must be honored with dignity and impartiality ${ }^{9}$.

In PACE resolution No. 1096 (1996) of 27/06/1996 (Section III), it is emphasized that analyzing the consequences of the application of this ideology (the communist note of the author), one should not attach importance to the similarity with the consequences of applying another ideology of the 20th century, but namely, of Nazism. However, although the criminal nature of the Nazi ideology and the Nazi regime is indisputable, at least for half a century, and its leaders and many criminals have incurred responsibility, the communist ideology and communist regimes have not met a comparable reaction. Crimes committed in the name of communism were a rare subject of judicial charges, and many criminals never appeared before a court. Communism is openly used, and the public awareness of the crimes of communism is very weak. This is especially obvious

\footnotetext{
8 https://www.oscepa.org/documents/all-documents/annual-sessions/2009-vilnius/declaration-6/2612009-vilnius-declaration-eng/file, p. 48-49

${ }^{9} \mathrm{http}: / /$ www.europarl.europa.eu/sides/getDoc.do?pubRef=-//EP//TEXT+TA+P6-TA-2008-

0439+0+DOC+XML+V0//EN
} 
when compared with public awareness of the crimes of Nazism.

Thus, at least 4 of the cited documents directly identify communism and Nazism: "European countries experienced two powerful totalitarian regimes, Nazi and Stalinist"; concern is expressed, in particular, by demonstrations "in commemoration of the Nazi or Stalinist past"; it refers to "mass deportations, murders and executions committed in the context of the acts of aggression of Stalinism and Nazism" falling "into the category of war crimes and crimes against humanity", points to the similarity of communist ideology "with the consequences of applying another ideology of the 20th century, namely, Nazism" and that "communist symbolism is openly used, and the public awareness of the crimes of communism is very weak". In this sense, it is absolutely unacceptable that the above mentioned position of the representative of the OSCE [7] states that Law No. 317-VIII, by prohibiting the propaganda of the communist totalitarian regime, threatens freedom of speech and the media, because it will never come to anyone's mind to cancel, for the sake of ensuring freedom of speech, bans on the propaganda of Nazism.

It should also be noted that the identification of communism and Nazism is adequately reflected in the scientific literature and speeches of objective publicists.

Thus, the scientist S. Grabovsky [11], justifying the impossibility of a radical delimitation of the said totalitarian regimes, notes that the program of actions set forth in the Manifesto of the Communist Party is no less bloodthirsty than the program of actions outlined in Mein Kampf. Therefore, both the 'excesses' of communism and the 'excesses' of Nazism are objectively predetermined by the general theoretical attitudes of both regimes. At the same time, the assertions about internationalism and the proletarian orientation of communism are greatly exaggerated. Thus, F. Engels in the years 1848-1849 defended the idea of uniting Germany with nationalist positions. In the article 'Democratic Pan-Slavism' Engels writes that the Croats as a nation are 
«counterrevolutionary by nature», that in addition to the Poles, Russians and most of all - the Turkish Slavs (that is, the Bulgarians, Serbs, Bosniaks), no Slavic people have a future [11].

In the thesis [23], in particular, it is pointed out that in the late 20's - early 30's. 20 tbsp. in the Russian Communist Party (the Bolsheviks) and the NSDAP there were great changes. Despite the slight differences in chronology, as well as in the nature of the political struggle, one can safely talk about the similarities in the evolution of the Russian Communist Party (the Bolsheviks) and NSDAP. The latter should include a single result of political struggle - the final approval of totalitarianism [23, p. 20].

Russian philosopher Prof. A.A. Ivin points out that there is an undeniable resemblance, for example, between the medieval feudal collectivist society and the modern forms of the socialist system of society, similar to communism or Nazism [13, p. 81]. The Nazi German state and the communist Soviet state are two variants of modern practical collectivism. Before their assertion as social systems, Nazism and communism existed in the form of the theory of the creation of a purely Aryan state and the Marxist-Leninist theory of building a communist society [13, p. 71]. Further, the professor points out that two different versions of the idea of a totalitarian party are the CPSU and the NSDAP. Both ignominiously are a thing of the past. But they showed with sufficient expressiveness how much disaster such a party can bring to their society [13, p. 116].

The Ukrainian writer and publicist Jan Valetov argues that Soviet power is an absolute evil... Soviet power was the absolute evil that deprived Russia of the chance to become a democratic European power forever. The same power broke the future for all countries around, and later, [spoiled life] on all continents, where it reached. Hitler's Nazi regime is the twin brother of the red dictatorship. Similarity should not be sought, it is on the surface, even on formal grounds, not to 
mention the essence. The difference is in the shade and color of the symbolism. Not more than [8].

In this aspect, the similarity of Soviet, especially Stalinist, socialism and German Nazism in the Ukrainian-language scientific literature was previously considered in the articles of the author [2,3] (2012-2013).

With this in mind, the symmetric condemnation of the communist and national-socialist (nazi) totalitarian regimes (Article 2 of the Law No. 317-VIII) is key and absolutely justified theoretically and practically. A comparison of the provisions of this article with respect to these regimes is given in Table 1.

Table 1

The wording of Article 2 of Law No. 317-VIII "Condemnation of the Communist and National Socialist (Nazi) Totalitarian Regimes"

\begin{tabular}{|c|c|}
\hline & \\
\hline $\begin{array}{l}\text { Communist totalitarian regime of } 1917-1991 \text { in } \\
\text { Ukraine is found criminal and the one that } \\
\text { exercised the policy of state terror characterized } \\
\text { by numerous violations of human rights in the } \\
\text { form of individual and mass murders, slaughters, } \\
\text { deaths, deportations, tortures, use of forced labour } \\
\text { and other forms of mass physical terror, } \\
\text { persecution for ethnic, national, religious, } \\
\text { political, class, social and other reasons, inflicting } \\
\text { mental and physical sufferings via application of } \\
\text { psychiatric measures for political purposes, } \\
\text { violation of the freedom of conscience, thought, } \\
\text { expression, press and lack of political pluralism } \\
\text { and due to these reasons it is condemned as } \\
\text { incompatible with the fundamental human and } \\
\text { citizens' rights and liberties }\end{array}$ & $\begin{array}{l}\text { National socialist (Nazi) totalitarian regime is } \\
\text { found criminal in Ukraine and the one that } \\
\text { exercised the policy of state terror } \\
\text { characterized by numerous violations of } \\
\text { human rights in the form of individual and } \\
\text { mass murders, slaughters, deaths, } \\
\text { deportations, tortures, use of forced labour } \\
\text { and other forms of mass physical terror, } \\
\text { persecution for ethnic, national, religious, } \\
\text { political, class, social and other reasons, } \\
\text { inflicting mental and physical sufferings via } \\
\text { application of psychiatric measures for } \\
\text { political purposes, violation of the freedom of } \\
\text { conscience, thought, expression, press and } \\
\text { lack of political pluralism and due to these } \\
\text { reasons, based on the facts established by the } \\
\text { Nurnberg International Military Tribunal of }\end{array}$ \\
\hline
\end{tabular}


1945-1946, it is condemned as incompatible with the fundamental human and citizen's rights and liberties

Thus, the characterization and condemnation of these two totalitarian regimes is absolutely symmetrical, except for mentioning in the context of the Nazi regime about the Nuremberg trial. However, regret about the absence of such a process with respect to totalitarian communism was repeatedly expressed in the resolutions of international structures cited above. Further, according to part 1 of Art. 3 of Law No.317-VIII, propaganda of communist and national socialist (Nazi) totalitarian regimes and their symbols shall be deemed outrage upon memory of millions of victims of the communist totalitarian regime, national socialist (Nazi) totalitarian regime and is prohibited by the law.

Thus, if this rule is valid for the Nazi totalitarian regime, then it is just as true for the communist totalitarian regime. Therefore, there are no grounds for criticism such and such provisions of the laws do not give them. Otherwise, we should agree with the justification of the ideology of Nazism.

Moreover, contrary to the statements of the experts of the Venice Commission, the definition of the concept of «propaganda» is given quite accurately. So, according to point 2 of part 1 of Art. 1 of Law No.317-VIII, propaganda of communist and national socialist (Nazi) totalitarian regimes a) public denial, in particular in mass media, of criminal nature of the communist totalitarian regime of 1917-1991 in Ukraine, national socialist (Nazi) totalitarian regime, dissemination of information oriented to find excuses to the criminal nature of the communist and national socialist (Nazi) totalitarian regimes, activities of the Soviet state security bodies, establishing Soviet rule in the territory of Ukraine or on its individual administrative territories, persecution of the fighters for independence of Ukraine in XX century, b) production and/or dissemination and public use of the products containing the symbols of the communist and 
national socialist (Nazi) totalitarian regimes.

This definition clearly states that criminal acts is to justify the communist totalitarian regime 1917-1991's, as well, and the National Socialist (Nazi) regime. There are no ambiguities here. An alternative can only be the praise of these modes.

On the other hand, the glorification of the left «Bolshevism» in terms of «protecting» the interests of workers is also inappropriate, because 'socialism' Hitler was far more focused on the needs of the employee than the 'socialism' of Stalin - suffice it to say that in mid-1930 s standard of living of ordinary working people 'true Aryan' was the highest in Europe, and the level of terror against the government of his subjects in Germany never achieved such a scale as in the USSR [11].

For example, in [17] summarized data regarding extrajudicial persecution Stalinist bodies VCHK-hcp NKVD-MGB-KGB. The data are given in Table 2.

Table 2

The number of persons brought to criminal responsibility and convicted to the maximum penalty by types of punitive organs for 1918-1953

\begin{tabular}{|l|c|c|c|c|c|c|}
\hline \multirow{2}{*}{ Показатель } & \multicolumn{3}{c|}{ Condemned by the types of punitive bodies } \\
\cline { 2 - 7 } & \multicolumn{2}{|c|}{ Court } & \multicolumn{2}{c|}{ Out-of-court } & \multicolumn{2}{c|}{$\begin{array}{c}\text { The punitive body } \\
\text { is unknown }\end{array}$} \\
\cline { 2 - 7 } & $\begin{array}{c}\text { total number } \\
\text { of persons }\end{array}$ & $\%$ & $\begin{array}{c}\text { total number } \\
\text { of persons }\end{array}$ & $\%$ & $\begin{array}{c}\text { total number } \\
\text { of persons }\end{array}$ & $\%$ \\
\hline $\begin{array}{l}\text { 1. Total number of persons } \\
\text { brought to criminal liability: }\end{array}$ & & & & & & \\
\hline total - 4.308.487 persons & & & & & & \\
\hline including: to capital & 1.324 .517 & 30,7 & 2.156 .278 & 50,0 & 827.692 & 19,3 \\
\hline $\begin{array}{l}\text { 2. Sentenced } \\
\text { punishment and shot }\end{array}$ & & & & & & \\
\hline total - 835.194 persons & 132.665 & 15,9 & 701.401 & 84,0 & 1.128 & 0,1 \\
\hline including: & & & & & & \\
\hline
\end{tabular}

The above data testify in particular that the extrajudicial bodies of the USSR 
were repressed by 2.156 .278 people, including 701.401 people $(84.0 \%)$ were sentenced to be shot. Moreover, in Nazi Germany, an extrajudicial body (the socalled «People's Court») sentenced 13.000 people to death [9]; in 166 times less.

Significantly more people died and suffered from the communist regimes from hunger, deportations, expulsions, other forms of repression without trial and any consequences in general. Thus, PACE resolution No. 1096 (1996) of 27/06/1996 gives the following data on the victims of communist regimes (million victims): USSR - 20, China - 65, Vietnam - 1, North Korea - 2, Kampuchea - 2, Eastern Europe - 1, Africa - 1,7, Afghanistan - 1,5. Behind these figures are the mass executions and executions of individuals, the death of people in concentration camps, the victims of hunger and deportations.

Numerous sacrifices and suffering brought totalitarian communist regime to the peoples of the USSR, primarily to Ukraine. The same PACE Resolution No. 1096 (1996) of 27/06/1996 specifies that 6 million Ukrainians died of starvation as a result of a well-conceived state policy in 1932-1933. There were destruction and deportation of hundreds of thousands of Poles, Ukrainians, Lithuanians, Latvians, Estonians, Moldovans, residents of Bessarabia in 1939-1941 and in 1944-1945; the deportation of the Volga Germans in 1941, Crimean Tartars in 1943, Chechens and Ingush in 1944. In particular, in the European Parliament resolution of 23/10/2008 «On the Holodomor of 1932-1933 in Ukraine» said that the European Parliament recognizes the Holodomor (an artificial famine of 193233) a terrible crime against the people of Ukraine and all of humanity; strongly condemns these actions directed against the Ukrainian peasantry, which were characterized by mass destruction and violation of human rights and freedoms.

Setting the existence of the 'worst' and 'best' variants of totalitarianism leads to absurd and blasphemous consequences. For example, the destruction of almost half of the Jews of Europe as a result of the Holocaust is terrible, but the destruction of almost half of the Crimean Tatars is unpleasant, but not so terrible. 
Is it possible to consider 'not terrible' mass deportations of the USSR - according to [20], in the Soviet Union were subjected to total deportation of ten people: Koreans, Germans, Finns, Ingrian, Karachai, Kalmyks, Chechens, Ingush, Balkars, Crimean Tatars and Meskhetians. Of these, seven - Germans, Karachais, Kalmucks, Ingush, Chechens, Balkars and Crimean Tatars - lost their national autonomies at the same time. Deportations in the USSR underwent still many other ethnic, ethno-religious and social categories of Soviet citizens: the Cossacks, «fists ${ }^{10} »$ of various nationalities, the Poles, Azerbaijanis, Kurds, Assyrians, Chinese, Russian, Iranians-Irani, Jews, Ukrainians, Moldovans, Lithuanians, Latvians, Estonians, Greeks, Bulgarians, Armenians, Hemshins, ArmeniansDashnaks, Turks, Tajiks and others [20].

In the context of the so-called «fist evictions» [20], it should be noted that Ukraine is also the most affected region. Thus, in Table 3 shows the number of evicted «fists» in the areas of eviction.

Table 3

The number of 'fists' of the first and second categories by eviction areas (thousands of families) [20]

\begin{tabular}{|c|c|c|}
\hline \multirow{2}{*}{ Regions } & \multicolumn{2}{|c|}{ Categorized } \\
\cline { 2 - 3 } & first & second \\
\hline the Average Volga & $3-4$ & $10-12$ \\
\hline the Lower Volga & $4-6$ & 20 \\
\hline North Caucasus and Dagestan & $6-8$ & 25 \\
\hline Central Black Earth Region & $3-5$ & $10-15$ \\
\hline Siberia & $5-6$ & $10-15$ \\
\hline Ural & $4-5$ & $30-35$ \\
\hline Kazakhstan & $5-6$ & $6-7$ \\
\hline Ukraine & 15 & $4-5$ \\
\hline Belarus & & \\
\hline
\end{tabular}

${ }^{10}$ The so-called well-off peasants in the USSR 


\begin{tabular}{|c|c|c|}
\hline Consuming regions of the RSFSR & 17 & 15 \\
\hline $\begin{array}{c}\text { National regions of Central Asia, the } \\
\text { Caucasus and the North Caucasus }\end{array}$ & 2,95 & \\
\hline In total, the upper bound & 79,95 & 169 \\
\hline
\end{tabular}

The above data indicate that more than $20 \%$ of the 'fists' families have been evicted from Ukraine from the entire evicted contingent. This also explains the impact on the country's agriculture, because it was about the most hardworking workers, distinguished by high productivity, knowledge and good organizational skills.

Of course, this does not mean that Hitler was better than Stalin, and the Nazis are better than the Bolsheviks; on the contrary, we are talking about the fact that they are identical, although A.I. Solzhenitsyn wrote about this in a somewhat different way: "On the whole planet and in all history there was no regime of more evil, bloody and at the same time more crafty-dodder than the Bolshevik, selfstyled 'Soviet'... neither by the number of tortured, nor through unified totalitarianism can any other terrestrial regime match it, not even the student Hitlerite, by that time eclipsed all eyes to the West" [22, p. 25]. Therefore, in any case, attempts to disrupt decommunization are no better than a desire to rehabilitate the Nazi regime and cross out the achievements of denazification [11].

It should also be borne in mind that the people, seemingly happily living under the rule of the Bolsheviks, did not have a special love for Bolshevik power. Not to mention the resistance of Sovietization during the civil war (see, for example, the Ganja uprising of 1920 mentioned above), in the USSR in the relatively quiet period (1957-1984), serious anti-government actions of workers took place (Table 4 [6]).

Table 4

Cases of riots in the USSR in 1957-1984 [6]

\begin{tabular}{|c|c|c|c|}
\hline Year & Regions & Year & Regions \\
\hline
\end{tabular}




\begin{tabular}{|c|c|c|c|}
\hline 1957 & Podolsk, Moscow region, Russia & 1967 & Frunze, Kyrgyzstan \\
\hline 1959 & Temirtau, Kazakhstan & 1967 & Chimkent, Kazakhstan \\
\hline 1961 & Kirovobad, Azerbaijan & 1967 & Pryluky, Ukraine \\
\hline 1961 & Biysk, Altai Territory & 1967 & Slutsk, Belarus \\
\hline 1961 & Krasnodar, Russia & 1967 & Stepanakert, Azerbaijan \\
\hline 1961 & Murom and Alexandrov, Russia & 1967 & Tula, Russia \\
\hline 1961 & Beslan, Ossetia & 1968 & Nalchik, Kabardino-Balkaria \\
\hline 1962 & Novocherkassk, Russia & 1972 & Dneprodzerzhinsk, Ukraine \\
\hline 1963 & Sumgait, Azerbaijan & 1974 & Rubtsovsk, Altai Territory \\
\hline 1963 & Krivoy Rog, Ukraine & 1977 & Novomoskovsk, Russia \\
\hline 1964 & Bronnitsy, Moscow region, Russia & 1981 & Ordzhonikidze, Ossetia \\
\hline 1964 & Stavropol, Russia & 1984 & Leninogorsk, Tatarstan \\
\hline
\end{tabular}

That is, for 30 post-war years, 24 cases of mass riots directed against the authorities were recorded. In 11 cases, weapons were used to suppress, as a result 43 people were killed and 166 wounded. Against 600 people were opened criminal cases. For the same time, 8.152 people were convicted for anti-Soviet propaganda and agitation. These are only those incidents that could not be suppressed in the bud [6].

With regard to concerns about the various prohibitions introduced by Law No. 317-VIII, it should be noted that according to Part 3 of Art. 4 of Law No. 317VIII, the prohibition does not cover the cases of using the symbols of communist totalitarian regime, the symbols of national socialist (Nazi) totalitarian regime: 1) in documents issued by public authorities or local self-governments (local public authorities) adopted or issued before 1991; 2) in documents issued by education and research institutions, enterprises, organizations before 1991; 3) in museum displays, thematic exhibitions, Museum Fund of Ukraine as well as in library stocks on various sources of information; 4) in works of art created before this Law comes into effect; 5) in the process of research activities including during scientific research and dissemination of their findings in the manner not prohibited 
by the legislation of Ukraine; 6) on original battle standards; 7) on state decorations, jubilee medals and other merit badges awarded to the persons before 1991 and during 1991-2015 for anniversaries of the events of the World War II period, and in the documents proving the award; 8) on memorial structures located within the burial sites, honourable burial sites; 9) during teaching or reconstructing (in particular, historical) of the historical events; 10) in private collections and private archive collections; 11) in trading in antique pieces. The prohibition does not cover the cases of using the symbols of communist totalitarian regime, the symbols of the national socialist (Nazi) totalitarian regime (providing this does not result in propaganda of criminal nature of the communist totalitarian regime of 1917-1991, criminal nature of the national socialist (Nazi) totalitarian regime: 1) in teacher's books, student's books and other materials of research and education nature intended for the use in training, educational and academic processes; 2) in the works of art created after this Law comes into effect.

Thus, the prohibitions imposed by Law No. 317-VIII do not limit museum, scientific activities, wearing awards, preserving symbols on graves, etc., which refutes most of the critical positions.

It should also be noted that according to Part 4 of Art. 3 of Law No. 317VIII, Where a legal entity, political party, other association of citizens, printed mass media source does not comply with this Law, its activities/publishing shall be ceased by court upon a claim to be initiated by a central executive authority responsible for implementing of the governmental policy on state registration of legal entities, registration (legalizing) of associations of citizens, non-governmental unions, other NGOs or other competent public authorities.

On the one hand, the transfer of such powers to the executive branch is questionable, since the adoption of such a decision can automatically cancel the registration of the relevant legal entity, so such decisions should be within the competence of the courts. However, on the other hand, there are no obstacles to 
appeal against decisions of non-compliance in court, which should be done in the law itself.

As for the problem of the proportionality of sanctions against violators, it should first of all be noted that the concept of proportionality is highly estimated. For example, since the adoption of the Criminal Code of Ukraine in 2001, article 436 «Propaganda of War» is envisaged there. This concept defines public appeals for an aggressive war or for the outbreak of a military conflict, as well as the production of materials with calls for such actions with a view to their dissemination or distribution of such materials. For such an act, the perpetrator can be sentenced to imprisonment up to 3 years.

According to the newly introduced article 436-1 of the Criminal Code «Manufacturing, dissemination of communist, Nazi symbols and propaganda of the communist and national-socialist (Nazi) totalitarian regimes», a possible sentence of up to 5 years is envisaged. Is this act more dangerous than that stipulated in Art. 436? To some extent yes. For example, the Russian author R. Shulga [24, p. 97] points out that the return of Stalin's view of history to Russian politics partly justifies Russia's aggressive policy towards Ukraine (the annexation of the Crimea and the participation of Russian servicemen in the armed conflict in the southeastern part of Ukraine)... after the expiration of almost 60 years since the 20th Congress of the CPSU, at which Stalin's policy was condemned, the Russian authorities are trying again to turn the wheel of history back, justifying the crimes of the totalitarian communist regime...

Thus, the propaganda of Stalinism is no less, and perhaps even more terrible crime in today's Ukraine than direct propaganda of war, and besides it is perceived today more sharply than in the peaceful 2001. By the way, in Art. 436-1 Criminal Code attitude to the communist and Nazi symbolism is absolutely symmetrical, which also refutes the incomprehensible origin of the thesis about the tolerant attitude of Law No. 317-VIII to Nazism. 
At the same time, Law No. 317-VIII creates the legal basis for access to the archives of repressive organs of the communist totalitarian regime of 1917-1991. So, according to part 4 of Art. 5 of Law No. 317-VIII, Archive documents, in particular, documents of former Soviet security service bodies related to political repressions, Holodomor (Great Famine) of 1932-1933 in Ukraine, other crimes committed by representatives of communist and national socialist (Nazi) totalitarian regimes as well as any information containing in them, shall not be classified information. The state shall disclose, provide the possibility to read and access the said archive documents and information they contain.

These legal bases are specifically implemented in Law No. 316-VIII [25].

With regard to the elimination of monuments associated with totalitarianism, as well as the corresponding renaming, it is necessary to understand that monuments and toponymy are essential factors of ideological influence on the population.

Thus, in the dissertation [15] it is noted that there is always a not always visible link between monuments and society. Monuments, being a part of the historical and cultural environment in which a person lives and develops as a social person, already have the influence of his physical existence on him, knowledge about the past history and culture and thereby - on the formation of his worldview. Already in ancient times, the authorities were perfectly aware of the great emotional power of the ideological influence of historical relics and monumental structures on the psyche and the consciousness of people. At the dawn of civilization in early states, historical relics were declared sacred and used by the authorities to unite society around the ideas it cultivated. Monumental propaganda did not spare money.

Thus, the presence of monuments of the totalitarian era of anti-Ukrainian meaning inhibits liberation from totalitarian ideology and hinders the strengthening of pro-Ukrainian ideology. 
Similarly, with toponymic names. So, in the publication [14] it is said that the name is destiny, so the name of the street on which a person lives, to some extent also predetermines his life. Characteristic in this sense is the title of the publication «Was born on Lenin's street - that's what you will be».

It should be noted that in the period of relatively democratic development, Russia, too, ignoring the costs, changed the names of quite large cities: Leningrad to St. Petersburg, Gorky to Nizhny Novgorod, Kuibyshev to Samara, Sverdlovsk to Ekaterinburg, and others.

It is also important to emphasize that decommunization is important not only as a factor in the restoration of historical memory and historical justice, but also as a factor in the rejection of the legal practice of the communist regime, namely, lawlessness, violation of human rights, substitution of legality by expediency. So, in Law No. 962-XII, the Verkhovna Rada of Ukraine... guarantees to the people of Ukraine that this will never happen again, that human rights and legality will be strictly observed. At the same time, the establishment of a strict legal order for the rehabilitation of victims of political repression in and of itself contributed to the strengthening of law and order in the republic. In the joint statement of 07/11/2003, the delegations of the UN member states regarding the 70th anniversary of the Holodomor in Ukraine 1932-33 expressed the conviction that exposing human rights violations, preserving historical documents and restoring the dignity of victims by recognizing their suffering will serve as a guide for future societies and help prevent similar catastrophes in the future. The preamble to Law No. 317-VIII states that the law is adopted, in particular, based on the need to ensure the protection of human and civil rights and freedoms, the desire to develop and strengthen an independent, democratic, rule-of-law state. In Art. 2 of the Law No.317-VIII (see Table 1), violations of the freedom of conscience, thought, expression, freedom of the press and the absence of political pluralism are 
recognized as inadmissible, which is recognized as incompatible with the fundamental rights and freedoms of man and citizen.

Conclusions. Thus, the adoption of a package of decommunization laws restores historical justice regarding the legitimate evaluation of the totalitarian communist regime, which has brought innumerable misfortunes to the Ukrainian people as to other peoples of the USSR, serves the interests of restoring the historical memory of the peoples subjected to Sovietization, and also facilitates the abandonment of illegal practices, the strengthening of the rule of law and respect for human rights in post-communist countries. The assertions about some special privileges of totalitarian socialism (communism) do not correspond to the positions of European democratic organizations of a human rights orientation, which they repeatedly expressed in the resolutions of collegial bodies - the PACE, the OSCE, the European Parliament.

\section{References}

1. Bez Henseka v holove [Without the Secretary General in my head] / RBK. Access mode: http://pda.rbtsdaily.ru/2015/04/10/polititss/562949994713707

2. Belkin L.M. Geneza problemy zabezpechennya zakonnosti v derzhavnomu upravlinni: do istoriyi pytannya [Genesis Problems of Law Enforcement in Public Administration: The History of the Issue] // Derzhavne upravlinnya: udoskonalennya ta rozvytok: Elektronne naukove fakhove vydannya [Public Administration: Improvement and Development: Electronic Scientific Professional Edition]. Access mode: http://dy.nayka.tsom.ua/index.php?operation $=1 \&$ iid=422

3. Belkin L.M. Doslidzhennya fenomenu zakonnosti yak instrumentu obmezhennya vlady: istoryko-pravovyy aspekt [Investigation of the phenomenon of legality as a tool for limiting power: the historical and legal aspect] / L.M. Belkin // Chasopys Akademiyi advokatury Ukrayiny [Journal of the Academy of Advocacy of Ukraine]. Access mode: http://nbuv.gov.ua/UJRN/ Chaau_2013_2_5 
4. Belkin L. Zakon pro dekomunizatsiyu ta Venetsians'ka komisiya: chy spravdi stalins'kyy rezhym ne zlochynnyy? [The Law on Decommissioning and the Venice Commission: Is Stalinist Regime Not Criminal?] // Yurydychna hazeta [Legal newspaper]. 19.01.2016. \# 1-2 (499-500), pp. 36-38.

5. Belkin L.M. Zakonyi Ukrainyi ot 9 aprelya 2015 goda o dekommunizatsii kak faktor vosstanovleniya istoricheskoy spravedlivosti [Laws of Ukraine of April 9, 2015 on de-communization as a factor in restoring historical justice] // Chasopis Akademiyi advokaturi Ukrayini [Journal of the Academy of Advocacy of Ukraine]. v. 8, \# 2, pp. 9-24. Access mode: http://nbuv.gov.ua/ UJRN/Chaau_2015_8_2_3

6. Bulgarov A. V SSSR ne prekraschalis narodnyie buntyi, o kotoryih nikto nikogda ne soobschal [People's riots did not stop in the USSR, of which no one has ever reported] // Natsionalnaya sluzhba novostey. Russkiy sektor [National news service. Russian sector]. Access mode: https://rusnsn.info/ analitika/v-sssr-neprekrashhalis-narodny-e-bunty-o-kotory-h-nikto-nikogda-ne-soobshhal.html

7. V OBSE schitayut, chto zakon o dekommunizatsii ugrozhaet svobode slova [The OSCE believes that the law on decommunization threatens freedom of speech] / GORDON. Access mode: http://gordonua.com/news/politics/V-OBSEschitayut-chto-zakon-o-dekommunizacii-ugrozhaet-svobode-slova-81439.html

8. Valetov Ya. Eto nashi. Nashim mozhno? [These are ours. Can we do it?] // Obozrevatel. Access mode: https://www.obozrevatel.com/society/ 27490-etonashi--nashim-mozhno.htm

9. Vipperman V. Evropeyskiy fashizm v sravnenii. 1922-1982 [European fascism in comparison. 1922-1982] // Per. s nem. A.I. Fedorova. Novosibirsk: Sibirskiy hronograf. 2000 [Translation from German A.I. Fedorov. Novosibirsk: The Siberian Chronograph. 2000]. Available at: http://www.ereading.org.ua/book.php?book=11543 
10. Glibovitskiy E. Tragediya Golodomora [The tragedy of the Holodomor] // ONLINE.UA. Access mode: https://news.online.ua/760287/ tragediyagolodomora-v-seti-poyavilas-vpechatlyayushchaya-infografika/

11. Grabovskiy S. Obershturmbanfyurer Putin i «zakonyi o dekommunizatsii» [Obersturmbannfuhrer Putin and the «laws on decommunization»] // Den [Day]. 19.05.2015. Available at: http://inosmi.ru/sngbaltia/20150519/228115313.html

12. Zakonami o dekommunizatsii vlast usugublyaet raskol $\mathrm{v}$ ukrainskom obschestve [The laws on decommunization are aggravated by the split in Ukrainian society] / N. Korolevskaya // Ofitsialnyiy sayt Oppozitsionnogo bloka [Official site of the Opposition bloc]. Access mode: http://opposition.org.ua/news/nataliyakorolevska-zakonami-pro-dekomunizaciyu-vlada-posilyue-rozkol-v-ukranskomususpilstvi.html

13. Ivin A.A. Osnovyi sotsialnoy filosofii : ucheb. posobie dlya vuzov [Fundamentals of Social Philosophy: Textbook, manual for high schools]. Moscow, 2005, 440 p. - ISBN 5-06-005126-9.

14. Idrisova A. Rodilsya na ulitse Lenina - takim i budesh [Was born on Lenin's street - that's what you will be] // Simbirskiy kurer [Simbirskiy courier]. 17.03.2001. \# 38-39. Available at: http://sm-k.narod.ru/ archives/2001/mar/3839/16.htm

15. Kulemzin A.M. Ohrana pamyatnikov v Rossii kak istoriko-kulturnoe yavlenie: dis... d-ra kulturol. nauk: [Protection of monuments in Russia as a historical and cultural phenomenon: a Doctor of Cultural Sciences' Thesis]. Tomsk, 2001, 403 p. Access mode: http://www.dissercat.com/content/okhranapamyatnikov-v-rossii-kak-istoriko-kulturnoe-yavlenie

16. Kulchitskiy S. Demograficheskie poteri Ukrainyi v XX veke [Demographic losses of Ukraine in the twentieth century] // Zerkalo nedeli [Mirror of the week], 01.10.2004. Access mode: https://zn.ua/SOCIETY/demograficheskie_poteri_ ukrainy_v_hh_veke.html 
17. Mozohin O.B. Pravo na repressii: Vnesudebnyie polnomochiya organov gosudarstvennoy bezopasnosti (1918-1953). Sudbyi. Sobyitiya. Dokumentyi. Versii [Right to repression: Extrajudicial powers of state security bodies (19181953). Fate. Developments. Documentation. Versions]. Moscow, 2006, 480 p. Available at: http://www.e-reading.club/bookreader. php/ 1010006/Mozohin__Pravo_na_repressii.html

18. Murguzov F. Gyandzhinskoe vosstanie 1920 goda, pervoe vooruzhYonnoe vyistuplenie protiv sovetizatsii Azerbaydzhana [Ganja uprising in 1920, the first armed attack against the Sovietization of Azerbaijan] // The Great Middle East. Access mode: http://thegreatmiddleeast.com/2017/01 /09/gandjinskoye-vosstaniye1920-goda/

19. Plotnikova A. Polskiy zakon o dekommunizatsii i reaktsiya Moskvyi [Polish law on decommunization and the reaction of Moscow] // Golos Ameriki. Access mode: https://www.golos-ameriki.ru/a/ai-polish-law-on-decommnization /39520 25.html

20. Polyan P.M. Ne po svoey vole... Istoriya i geografiya prinuditelnyih migratsiy v SSSR [Not by choice ... History and geography of forced migrations in the USSR]. Moscow, 2001. Available at: http://demoscope.ru /weekly/knigi/ polian/polian.html

21. Rishennya «Venetsianky» pro dekomunizatsiyu: meta lehitymna, ale zakon potribno zminyty [Venecians' decision on decommissioning: the goal is legitimate, but the law needs to be changed] / Ukrayins'ka pravda [Ukrainian truth]. Access mode: http://www.eurointegration.tsom.ua/news/2015/ 12/19/7042483/

22. Solzhenitsyin A. Arhipelag GULag. Tekst knigi na sayte A. Solzhenitsyina Gulag Archipelago. The text of the book is on the site of A. Solzhenitsyn. Vol. 3. 308 p. Available at: http://www.solzhenitsyn.ru/ proizvedeniya/arhipelag_gulag/ arhipelag_gulag_tom3.pdf 
23. Shlotgauer V.O. Karatelnyie organyi Sovetskogo gosudarstva i natsistskoy Germanii v 30-e godyi (sravnitelno-pravovoy analiz): avtoref. dis... kand. yurid. nauk [Punitive organs of the Soviet state and Nazi Germany in the 30 years (comparative legal analysis): PhD in Law Abstract of Diss.]. Krasnodar, 2010, 35 p. Available at: http://kubsau.ru/upload/iblock/37b/37b454cf5aba 6cebac9c9 ea01170e802.pdf

24. Shulga R.Yu. Zabyit istoriyu: ofitsialnaya politika pamyati v sovremennoy Rossii (yuridicheskoe izmerenie) [Forget history: the official policy of memory in modern Russia (the legal dimension)] // Gumanitarnyie nauki i modernizatsiya pravovoy sistemyi gosudarstva: rossiyskiy i zarubezhnyiy opyit: Trudyi IV mezhdunarodnoy nauchno-prakticheskoy konferentsii / pod red. G.B. Gridnevoy, A.B. Didikina [Humanitarian sciences and modernization of the legal system of the state: Russian and foreign experience: Proceedings of the IV International Scientific and Practical Conference / ed. G.B. Gridneva, A.B. Didikina]. Novosibirsk, 2015, pp. 94-100.

25. Yurynets' Yu.L. Zakon Ukrayiny \# 316-VIII shchodo dostupu do arkhiviv represyvnykh orhaniv komunistychnoho totalitarnoho rezhymu $\mathrm{v}$ konteksti demokratychnykh zakhidnykh tradytsiy [Law of Ukraine No. 316-VIII on access to archives of repressive bodies of the communist totalitarian regime in the context of democratic western traditions] // Administratyvne pravo i protses [Administrative law and process]. 2015. \# 2 (12), pp. 6-15.

26. Yarmoshchuk T. Dekomunizatsiyni zakony porushuyut' svobodu slova? [Decommissioning laws violate freedom of speech?] // Radio Svoboda [Radio Liberty]. Available at: http://www.radiosvoboda.org/ content/article/26973605. html 